\section{Histochemistry through the years, browsing a long-established journal: novelties in traditional subjects}

\section{Pellicciari}

Dipartimento di Biologia Animale, University of Pavia, Italy

\section{Abstract}

Histochemical journals represent a traditional forum where methodological and technological improvements can be presented and validated in view of their applications to investigate not only cytology and histology in normal and diseased conditions but to test as well hypotheses on more basic issues for life sciences, such as comparative and evolutionary biology. The earliest scientific journals on histochemistry began their publication in the first half of the ' $50 \mathrm{~s}$ of the last century, and their readership did not probably change over the years; rather, the authors' interests may have progressively been changing as well as the main topics of their articles. This hypothesis is discussed, based on the subjects of the article published in the first and last ten years in the European Journal of Histochemistry, as an example of old journal which started publication in 1954, being since then the official organ of the Italian Society of Histochemistry. This survey confirmed that histochemistry has provided and still offers unique opportunities for studying the structure, chemical composition and function of cells and tissues in a wide variety of living organisms, especially when the topological distribution of specific molecular components has diagnostic or predictive significance, as it occurs in human and veterinary biology and pathology. Some subjects (e.g. histochemistry applied to muscle cells or to mineralized tissues) have recently become rather popular, whereas a wider application of the histochemical approach may be envisaged for plant cells and tissues.

In recent years, microscopy and histochemistry have been undergoing a sort of Renaissance, being recognized as essential tools to perform accurate studies of cell and molecular biology, as they allow detecting in situ specific molecules at the very place where they are functionally active, in vivo. As a consequence, a large and ever growing number of histochemically-driven articles on cell and tissue biology has not been published in strictly histochemical journals, but in different publications dealing with cell and molecular biology, medicine or biotechnology

Such an evolution was surely in the will and hope of the Fathers of histochemistry when, in the years ' $50 \mathrm{~s}$ to ' 60 s of the last century, histochemistry lived its golden age in Europe and the USA, with an extraordinary development of new methods, probes, and technologies. However, this wider application of histochemistry in biomedical research apparently did not result in a proportional increase of the impact of the histochemical journals on the scientific community, despite their fundamental role in promoting innovation, and the continuous implementation of dedicated instruments and techniques.

It is likely that the readership of the journals devoted to cytochemistry and histochemistry did not change significantly, over the years; rather, the authors' interests may have progressively been changing as well as the main topics of their articles.

In a probably naïve attempt to test this hypothesis, I have compared the subjects of the papers published in the European Journal of Histochemistry in the last ten years (20012010), with those published in the first ten years of publication of this Journal under the title Rivista di Istochimica Normale $e$ Patologica (1954-1963). For sake of simplicity, the articles have been arbitrarily divided into ten categories: Human biology \& histopathology; Animal biology \& veterinary medicine; Methods \& techniques; Cell nucleus; Neurobiology \& neuroendocrinology; Connective tissue, bone \& cartilage; Muscle tissue; Development \& stem cells; Cell proliferation \& death; Plant cell biology.

There are several reasons for selecting the European Journal of Histochemistry (besides that I am the present Editor, of course!): this is an old journal (it was founded and started publication in 1954) and, since its foundation, it has been the official organ of the Italian Society of Histochemistry that has always been composed of scientists working in a wide variety of biological fields, from cell and tissue biology, to human and veterinary medicine, microscopy, cytometry, zoology, ecology, botany. Indeed, the Founders of the journal wrote in their opening note to the first issue ${ }^{1}$ that they did not aim at adding a new journal to the already large number of publications on normal biology and pathology, rather they intended to provide a forum for all those scientists approaching research in biology through histological and chemical methods in situ. In their vision, histochemistry should be viewed as a fundamental tool to investigate the peculiar histo- and cytological features of pathological tissues compared to the normal ones, besides as the proper approach to face basic biological problems through the study of a wide variety of living organisms; to this purpose, the setting-
Correspondence: Carlo Pellicciari, Dipartimento di Biologia Animale, Università degli Studi di Pavia, via A. Ferrata 9, 27100 Pavia, Italy.

E-mail: pelli@unipv.it

Received for publication: 6 December 2010 . Accepted for publication: 10 December 2010.

This work is licensed under a Creative Commons Attribution 3.0 License (by-nc 3.0).

(C) Copyright C. Pellicciari, 2010

Licensee PAGEPress, Italy

European Journal of Histochemistry 2010; 54:e51 doi:10.4081/ejh.2010.e51

up, or the improvement, of increasingly refined methods and techniques for the detection of different molecules in tissues and cells was and still remains crucial.

Consistently, if the papers published in the first and last ten years of the journal are considered as a unique sample (Figure 1A), about $60 \%$ of the articles falls into three categories: Human biology \& histopathology, Animal biology \& veterinary medicine, Methods \& techniques. In the same periods, relatively fewer articles (about 15\%) have, on the contrary, been devoted to Connective tissue, Bone \& cartilage, Muscle tissue, Cell proliferation, Differentiation \& death, and Plant cell biology.

Comparing the first ten years of publication with the last ten ones (Figure 1B), it is however apparent that authors' interests did change. As expected, articles on methods and techniques were especially present in the first years of the journal when they were close to 23\%. The papers on Human biology \& histopathology and those on Animal biology \& veterinary medicine were also more frequent in the first years. The total incidence of these three categories dropped from $70 \%$ to about $50 \%$, in the last ten years. On the opposite, there was a significant increase in the percentage of articles devoted to Muscle tissue, Connective tissue, Bone \& cartilage, Cell proliferation \& death, and Plant cell biology, representing the $22 \%$ of the published papers in the last decade.

As a general comment, in the years 1954-63 of the journal, histochemistry was mostly applied for descriptive purposes either to compare normal and pathological tissues in humans or animal species, or to provide an in situ chemical evidence for comparative studies on tissues and organs from adult or developing organisms. This is perfectly understandable, taking into account the relatively poor knowledge, in those years, of the various molecular compositions of normal and pathological cells and tissues, which made the topological detection of different chemical components especially attractive. At the same time, there was 
an intense effort to establish staining protocols and to define the most appropriate experimental conditions for the application of histochemical techniques.

Especially in the most recent (last fiveyears) period, relatively few descriptive articles have been published on human cytology and histology, either normal ${ }^{2-7}$ or pathological. ${ }^{8-14}$ Few papers only were aimed at comparing the expression of specific proteins of normal versus diseased (mainly tumour) tissues, ${ }^{15-18}$ whereas most of them were addressed to identify diagnostic and prognostic indicators ${ }^{19-24}$ or to elucidate the pathogenetic mechanisms or the progression markers of diseases. ${ }^{22,25-34}$ Similarly, purely descriptive articles on neurobiology field have been quite rare in the last years, ${ }^{35,36}$ while the great majority focuses on structural and functional relationships between the neural and endocrine systems. ${ }^{3744}$

As for Animal biology \& veterinary medicine, besides the descriptive articles, ${ }^{42,45-51}$ most of the recently published paper dealt with the application of histochemical techniques to monitor the effects of infections, environmental stress or pollution on different organs and tissues. ${ }^{52.66}$

Among the recent articles on methodology, it is interesting to observe that there has been a special interest for techniques aimed at investigating scarce biological samples or archive histological material from rare human diseases ${ }^{67-72}$ in this view, the validation of new selective antibodies has a great importance. ${ }^{73,74}$ Rather surprisingly, fixation and embedding procedures still represent key passages in sample preparation, which deserve investigating whenever particular chemical components ${ }^{75,76}$ or cell and tissues features from poorly studied species $^{77}$ are to be investigated. Articles were also published on the application of quantum dots, i.e. the most recent luminescent probes, to label subcellular structures, ${ }^{78,79}$ or on dedicated software for cell type classification or 3D reconstruction from optical images. $^{80,81}$

In the long history of the European Journal of Histochemistry, the study of the cell nucleus by qualitative and quantitative methods has actually been one of the most represented subjects. More than 260 articles have been published since 1954, dealing with either basic bio-cellular aspects or the peculiar features of nuclei from pathological tissues. This attitude has become especially evident during the last few years, when several published papers concerned the structural organization of the nuclear components in cells under normal, pathological or experimental conditions. ${ }^{82-90}$ In the attempt to precisely localize specific nuclear components, multiple immunohistochemical techniques at transmission electron microscopy have been widely used: this approach proved to be especially appropriate to investigate functional changes in the cell nuclei from different tissues, ${ }^{91-92}$ and in particular to study synthesis and processing of nuclear RNAs in normal and pathological conditions. ${ }^{93-94}$ As underlined by our late lamented honorary-Editor, professor Maria Gabriella Manfredi Romanini Nuclear histochemistry represents a real molecular biology in situ applied to research on dynamic processes in the nucleus, and this makes the microscopic and histochemical approach absolutely irreplaceable for the progress in our understanding of cell biology. ${ }^{95}$

Histochemical research on muscle tissues and cells has strongly increased in the international literature, during the last few years: 3800 articles have been published in peerreviewed journals in the period 2005-2009, compared to the total number of about 13,000 published in 1965-2004 (data available at URL http://www.ncbi.nlm.nih.gov/pubmed), the number of articles annually published in the last five years being more than twice the average number of papers that have been published per year in 1965-2004. As reported by Malatesta and Meola, ${ }^{94}$ again the in situ analysis of cell nucleus may represent a key factor to understand the basic mechanisms leading to fibre muscle loss/disorganization. Actually, nuclear histochemistry has provided significant contribution to the progress of knowledge in sarcopenia, ${ }^{93,96,97}$ and the cytochemical analysis of the cell nucleus of myocytes and satellite cells revealed an interesting relationship between the occurrence of sarcopenia or dystrophy and the changes in the structural and functional features of chromatin and the ribonucleoprotein containing structures involved in RNA processing. ${ }^{98-100}$ The combination of biomolecular analyses with the in situ cytochemical techniques also demonstrated that the basic mechanisms of some pathologies (e.i. the myotonic dystrophy type 2 and laminopathies) relate to an altered organization of nuclear structures..$^{91,98}$ The expression of several different cytoplasmic proteins has been studied in situ, to investigate the structure and function of skeletal and heart muscle cells during differentiation and aging ${ }^{101-103}$ or under experimental conditions, such as inactivity or endurance-training..$^{104,105}$

Histochemical research on mineralized tissues recently became a popular subject in the European Journal of Histochemistry. Following his presentation at the XXXII Congress of the Italian Society of Histochemistry as the 2007 Awardee of the Maffo Vialli International Award, Antonio Nanci wrote an interesting paper on the immunodetection of matrix proteins in calcified tissues, ${ }^{106}$ and then other articles concerned predentine/dentine matrix, ${ }^{107-109}$ or the process of osteoclastogenesis. ${ }^{110-112}$ In
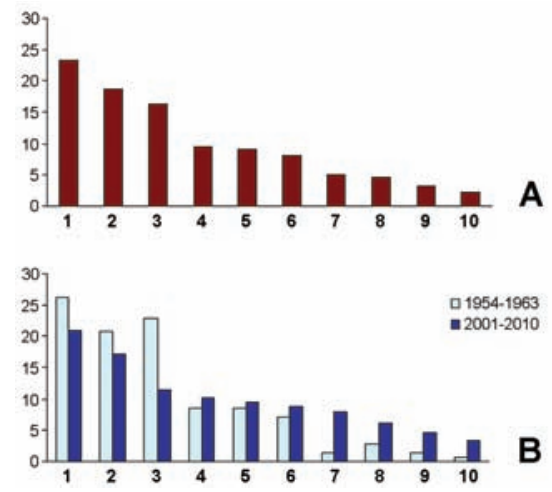

Figure 1. A. Percentage of the articles on different subjects published in the European Journal of Histochemistry during the first (1954-1963) and last (2001-2010) decades, considered as a pooled sample. B. Comparison of the article percentages between the first and last decade. The article subjects reported in the abscissa axis are the following: 1 . Animal biology \& veterinary medicine; 2. Human biology \& histopathology; 3. Methods \& techniques; 4. Development $\&$ stem cells; 5 . Neurobiology \& neuroendocrinology; 6. Cell nucleus; 7. Muscle tissue: 8 . Connective tissue, bone $\&$ cartilage; 9. Cell proliferation \& death; 10. Plant cell biology.

some of these investigations, cell models in culture have been used, with special attention to the application of bone and cartilage precursors for tissue engineering. ${ }^{113,114}$

The expression of specific proteins has been studied by immunohistochemistry also in other stem cells derived cultures driven to differentiate into myocytes, ${ }^{115}$ cardiomyocytes ${ }^{116}$ or smooth muscle cells. ${ }^{117}$

The potential of histochemical and microscopical techniques for investigating stem cell biology and embryonic development was underlined during a symposium held in Pavia (Italy) in $2008,{ }^{118}$ and several articles have been devoted to differential gene expression during the embryogenesis of organs and systems from different animal species, ${ }^{6,119-128}$ with special attention to the lymphoid organs in birds, ${ }^{129,130}$ and mammals, ${ }^{35,43}$ during their development under unperturbed or experimental conditions. Interestingly, the functional role of haemocytes has also been studied in some Invertebrates ${ }^{131,132}$ providing important clues on the origin and evolution of the immune system in vertebrates.

\section{Concluding Remarks}

It is actually impossible to predict the future trends of histochemical research (and consequently the subjects of the articles that will 
appear in histochemical journals); this will essentially depend on the hot topics that will emerge in biology and biomedicine, as well as on the unpredictable development of novel instruments and technologies in the next years.

The very small sample (less than 800 articles) considered in the present survey, however, confirms that histochemistry has provided and still offers unique opportunities for the study of structure, chemical composition and function of cells and tissues in a wide variety of living organisms, especially when the topological distribution of specific molecular components has diagnostic or predictive significance. Consistently, it may be expected that human and veterinary biomedicine will represent, also in the future, the main application fields of histochemistry.

The still rather large number of recent articles concerning basic biological investigations on lower Vertebrates and Invertebrates also suggests that histochemistry is the appropriate tool for drawing reliable correlations between microanatomy and physiology in tissues and organs from still poorly described organisms. Through a comparative approach, histochemical evidence in parallel with molecular data on protein and DNA will provide clues for elucidating the origin and evolution of cellular systems and physiological functions.

A wide development of histochemical research will especially be possible in the field of plant biology, where the number of histochemical articles published has so far been relatively small: less than 400 articles may be found in the literature since the ' $50 \mathrm{~s}$ of the last century, but about 200 have been published in the last ten years, suggesting that the histochemical approach is becoming increasingly attractive for plant biologists, too (source: http://www.scirus.com/ and http://apps.isiknowledge.com).

As a final observation, it is worth emphasizing that histochemical journals still represent the distinctive forum where methodological and technological improvements can be presented and validated in view of their applications to investigate not only cytology and histology in normal and diseased conditions but also to test hypotheses on more basic issues for life sciences, such as comparative and evolutionary biology.

\section{References}

1. Barigozzi C, Bignardi C, Bozza G, Bruni AC, Ciafardi E, Redaelli P et al., Editorial. Riv Istoch Norm Pat 1954;1:34.

2. Porzionato A, Macchi V, Amagliani A,
Castagliuolo I, Parenti A, De Caro R. Neurotensin receptor 1 immunoreactivity in the peripheral ganglia and carotid body. Eur J Histochem 2009;53:135-42.

3. Bilinska B, Kotula-Balak M, Sadowska J. Morphology and function of human Leydig cells in vitro. Immunocytochemical and radioimmunological analyses. Eur J Histochem 2009;53:35-42.

4. Rovati B, Mariucci S, Manzoni M, Bencardino K, Danova M. Flow cytometric detection of circulating dendritic cells in healthy subjects. Eur J Histochem 2008;52:45-52.

5. Kiga N, Tojyo I, Matsumoto T, Hiraishi Y, Shinohara Y, Fujita S. Expression of lumican in the articular disc of the human temporomandibular joint. Eur J Histochem 2010;54(3):e34.

6. Nemolato S, Cabras T, Fanari MU, Cau F, Fanni D, Gerosa C et al. Immunoreactivity of thymosin beta 4 in human foetal and adult genitourinary tract. Eur J Histochem 2010;54(4):e43.

7. Sbarbati A, Accorsi D, Benati D, Marchetti L, Orsini G, Rigotti G et al. Subcutaneous adipose tissue classification. Eur J Histochem 2010;54:e48.

8. Zulli A, Burrell LM, Buxton BF, Hare DL. ACE2 and AT4R are present in diseased human blood vessels. Eur J Histochem 2008;52:39-44.

9. Fanni D, Nemolato S, Ganga R, Senes G, Gerosa C, Van Eyken P, et al. Cytokeratin 20-positive hepatocellular carcinoma. Eur J Histochem 2009;53:269-74.

10. Pilloni L, Manieli C, Senes G, Ribuffo D, Faa G. Merkel cell carcinoma with an unusual immunohistochemical profile. Eur J Histochem 2009;53:275-8.

11. Ruggeri RM, Ferraù $F$, Campennì $A$, Simone A, Barresi V, Giuffrè G et al. Immunohistochemical localization and functional characterization of somatostatin receptor subtypes in a corticotropin releasing hormonesecreting adrenal phaeochromocytoma: review of the literature and report of a case. Eur J Histochem 2009;53:1-6.

12. Sharma P, Kar R, Dutta S, Pati HP, Saxena R. Niemann-Pick disease, type B with TRAP-positive storage cells and secondary sea blue histiocytosis. Eur J Histochem 2009;53: 183-6.

13. Cortés-Gutiérrez EI, Dávila-Rodríguez MI, Fernández JL, López-Fernández C, Gosálvez J. Koilocytes are enriched for alkaline-labile sites. Eur J Histochem 2010;54:e32.

14. Ruggeri RM, Vitarelli E, Barresi G, Trimarchi F, Benvenga S, Trovato M. The tyrosine kinase receptor c-met, its cognate ligand hgf and the tyrosine kinase receptor trasducers stat 3 , pi3k and rho in thyroid nodules associated with Hashimoto's thyroiditis: an immunohistochemical characterization. Eur J Histochem 2010;54:e24.

15. Xu W, Li X, Chen S, Huang J, Lin S, Lin J, et al. Expression and distribution of $\mathrm{S}$ 100, CD83 and apoptosis-related proteins (Fas, FasL and Bcl-2) in tissues of thyroid carcinoma. Eur $\mathrm{J}$ Histochem 2008;52:153-62.

16. Kalnina $\mathrm{Z}$, Silina $\mathrm{K}$, Bruvere $\mathrm{R}$, Gabruseva N, Stengrevics A, BarnikolWatanabe S, et al. Molecular characterisation and expression analysis of SEREX-defined antigen NUCB2 in gastric epithelium, gastritis and gastric cancer. Eur J Histochem 2009;53:7-18.

17. Nemolato S, Cabras T, Fanari MU, Cau F, Fraschini M, Manconi B, et al. Thymosin beta 4 expression in normal skin, colon mucosa and in tumor infiltrating mast cells. Eur J Histochem 2010;54:e3.

18. Salemi M, Calogero AE, Zaccarello G, Castiglione R, Cosentino A, Campagna $\mathrm{C}$, et al. Expression of SPANX proteins in normal prostatic tissue and in prostate cancer. Eur J Histochem 2010;54:e41.

19. Alexandrakis MG, Passam FH, Dambaki K, Nalbanti F, Stathopoulos ES, Kyriakou DS. The assessment of proliferating cell nuclear antigen immunostaining in myelodysplastic syndromes and its prognostic significance. Eur $\mathrm{J}$ Histochem 2005;49:27-32

20. Fukuda M., Sun A. The DNA-instability test as a specific marker of malignancy and its application to detect cancer clones in borderline malignancy. Eur $\mathrm{J}$ Histochem 2005;49:11-26.

21. Hirose M, Sun A, Okubo T, Noriki S, Imamura Y, Fukuda M. Detection of nonpapillary, non-invasive transitional cell G1 carcinoma as revealed by increased DNA instability and other cancer markers. Eur J Histochem 2005;49:199-210.

22. Giuffrè G, Barresi V, Catalano A, Cappiello A, Stagno d'Alcontres F, Tuccari G. Actinic keratosis associated with squamous and basal cell carcinomas: an evaluation of neoplastic progression by a standardized AgNOR analysis. Eur J Histochem 2008;52:53-60.

23. Lai G, Nemolato S, Lecca S, G Parodo, Medda C, Faa G. The role of immunohistochemistry in the diagnosis of hyalinizing clear cell carcinoma of the minor salivary gland: a case report. Eur J Histochem 2008;52:251-4.

24. Perrone G, Morini S, Santini D, Rabitti C, Vincenzi B, Alloni R, et al. Human equilibrative nucleoside transporter 1 and carcinoma of the ampulla of Vater: 
expression differences in tumour histotypes. Eur J Histochem 2010;54:e38.

25. Martelli AM, Cocco L, Capitani S, Miscia S, Papa S, Manzoli FA. Nuclear phosphatidylinositol 3,4,5-trisphosphate, phosphatidylinositol 3-kinase, Akt, and PTen: emerging key regulators of antiapoptotic signaling and carcinogenesis. Eur J Histochem 2007;51(Suppl 1):12531.

26. Campanella C, Bucchieri F, Ardizzone NM, Marino Gammazza A, Montalbano A, Ribbene A, et al. Upon oxidative stress, the antiapoptotic Hsp60/procaspase-3 complex persists in mucoepidermoid carcinoma cells. Eur J Histochem 2008;52:221-8.

27. Cvejic D, Selemetjev S, Savin S, Paunovic I, Tatic S. Changes in the balance between proliferation and apoptosis during the progression of malignancy in thyroid tumours. Eur J Histochem 2009;53:65-72.

28. Gonelli A, Milani D, Rimondi E, Voltan R, Grill V, Celeghini C. Activation of PKC-e counteracts maturation and apoptosis of HL-60 myeloid leukemic cells in response to TNF family members. Eur J Histochem 2009;53:177-82.

29. Pilloni L, Bianco P, Manieli C, Senes G, Coni P, Atzori L et al. Immunoreactivity for alpha-smooth muscle actin characterizes a potentially aggressive subgroup of little basal cell carcinomas. Eur $\mathbf{J}$ Histochem 2009;53:113-6.

30. Artico M, Bronzetti E, Alicino V, Ionta B, Bosco S, Grande C, et al. Human gallbladder carcinoma: role of neurotrophins, MIB-1, CD34 and CA15-3. Eur J Histochem 2010;53:e10.

31. Artico M, Bronzetti E, Ionta B, Bruno M, Greco A, Ruoppolo G, et al. Reinke's Edema: investigations on the role of MIB-1 and hepatocyte growth factor. Eur J Histochem 2010;54:e30.

32. Loreto C, Almeida LE, Migliore MR, Caltabiano M, Leonardi R. TRAIL, DR5 and caspase 3-dependent apoptosis in vessels of diseased human temporomandibular joint disc. An immunohistochemical study. Eur J Histochem 2010;54:e40.

33. Matsumoto T, Inayama M, Tojyo I, Kiga $\mathrm{N}$, Fujita S. Expression of hyaluronan synthase 3 in deformed human temporomandibular joint discs: in vivo and in vitro studies. Eur $\mathrm{J}$ Histochem 2010;54:e50.

34. Nowak D, Mazur AJ, Popow-Woźniak A, Radwańska A, Mannherz HG, MalickaBłaszkiewicz M. Subcellular distribution and expression of cofilin and ezrin in human colon adenocarcinoma cell lines with different metastatic potential. Eur J Histochem 2010;54:e14.

35. Demonceau C, Marshall AS, Sales J, Heinen E. Investigation of close interactions between sympathetic neural fibres and the follicular dendritic cells network in the mouse spleen. Eur J Histochem 2008;52:85-92.

36. Ragionieri L, Botti M, Gazza F, Bo Minelli L, Acone F, Panu R, et al. Double labelling immunohistochemical characterization of autonomic sympathetic neurons innervating the sow retractor clitoridis muscle. Eur J Histochem 2008;52:29-38.

37. Lepore G, Gadau S, Mura A, Arru B, Mulliri G, Zedda M, et al. Androgen receptor immunoreactivity in rat occipital cortex after callosotomy. Eur J Histochem 2008;52:163-8.

38. Lucini C, Maruccio L, Antonucci R, Castaldo L. Immunoreactivity to glial cell line-derived neurotrophic factor and its receptors in the trout pancreas: a further endocrine-exocrine relationship? Eur J Histochem 2008;52:69-74.

39. Squillacioti C, De Luca A, Paino G, Mirabella N. Effects of castration on the immunoreactivity to NGF, BDNF and their receptors in the pelvic ganglia of the male rat. Eur J Histochem 2008;52:101-6.

40. Trifunovic S, Filipovic B, Ajdžanovic V, Šošic-Jurij B, Manojlovic-Stojanoski M, Nestorovic N, et al. The effects of chronic SRIH-14 and octreotide administration on the pituitary-adrenal axis in adult male rats. Eur J Histochem 2008; 52:61-8.

41. Zhao W, Shen H, Yuan F, Li G, Sun Y, Shi $\mathrm{Z}$, et al. Induction stage-dependent expression of vascular endothelial growth factor and aquaporin-1 in diethylstilbestrol-treated rat pituitary. Eur J Histochem 2009;53:53-60.

42. Acosta M, Filippa V, Mohamed F. Folliculostellate cells in pituitary pars distalis of male viscacha: immunohistochemical, morphometric and ultrastructural study. Eur J Histochem 2010;54:e1.

43. Mignini F, Sabbatini M, D'Andrea V, Cavallotti C. Intrinsic innervation and dopaminergic markers after experimental denervation in rat thymus. Eur $\mathrm{J}$ Histochem 2010;54:e17.

44. Sandhu MA, Rahman ZU, Riaz A, Rahman SU, Javed I, Ullah N. Somatotrophs and lactotrophs: an immunohistochemical study of Gallus domesticus pituitary gland at different stages of induced moult. Eur J Histochem 2010;54:e25.

45. Dall'Aglio C, Pascucci L, Mercati F,
Giontella A, Pedini V, Scocco P, et al. Identification of orexin A- and orexin type 2 receptor-positive cells in the gastrointestinal tract of neonatal dogs. Eur J Histochem 2008;52:229-36.

46. Huang $\mathrm{YH}$, Jiang $\mathrm{M}, \mathrm{Fu}$ BY. Immunocytochemical localization of monoamine oxidase type $B$ in rat liver. Eur J Histochem 2008;52:11-8.

47. Palmieri G, Acone F, Desantis S, Corriero A, Ventriglia G, Addis P, et al. Brain morphology and immunohistochemical localization of the gonadotropin-releasing hormone in the bluefin tuna, Thunnus thynnus. Eur J Histochem 2008;52:19-28.

48. Huang YH, Sun MJ, Jiang M, Fu BY. Immunohistochemical localization of glucagon and pancreatic polypeptide on rat endocrine pancreas: coexistence in rat islet cells. Eur J Histochem 2009; 53:81-6.

49. Imura K, Sato I. Identification of the novel localization of tenascinX in the monkey choroid plexus and comparison with the mouse. Eur $\mathrm{J}$ Histochem 2009;53:225-32.

50. Ćirović S, Marković-Lipkovski J, Todorović J, Nešović-Ostojić J, Jović M, Ilić $\mathrm{S}$, et al. Differential expression of $\mathrm{KCNQ} 1 \mathrm{~K}+$ channel in tubular cells of frog kidney. Eur J Histochem 2010;54:e7.

51. Lovasova K, Kluchova D, Bolekova A, F Dorko, Spakovska T. Distribution of NADPH-diaphorase and AChE activity in the anterior leaflet of rat mitral valve. Eur J Histochem 2010;54:e5.

52. Abban G, Yildirim NB, Jetten AM. Regulation of the vitamin D receptor and cornifin beta expression in vaginal epithelium of the rats through vitamin D3. Eur J Histochem 2008;52:107-14.

53. Poltronieri C, Negrato E, Bertotto D, Majolini D, Simontacchi C, Radaelli G. Immunohistochemical localization of constitutive and inducible Heat Shock Protein 70 in carp (Cyprinus carpio) and trout (Oncorhynchus mykiss) exposed to transport stress. Eur J Histochem 2008;52:191-8.

54. Zanuzzi CN, Fontana PA, Barbeito CG, Portiansky EL, Gimeno EJ. Paneth cells: histochemical and morphometric study in control and Solanum glaucophyllum intoxicated rabbits. Eur J Histochem 2008; 52:93-100.

55. Kovsca Janjatovic A, Lackovic G, Bozic F, Spoljaric D, Popovic M, Valpotic H, et al. Histomorphometric characteristics of immune cells in small intestine of pigs perorally immunized with vaccine candidate F18ac+ nonenterotoxigenic E. coli strain. Eur J Histochem 2009;53:189-98. 
56. Lepore G, Gadau S, Mura A, Zedda M, Farina V. Aromatase immunoreactivity in fetal ovine neuronal cell cultures exposed to oxidative injury. Eur J Histochem 2009;53:233-8.

57. Magi GE, Lopez-Romalde S, Magariños B, Lamas J, Toranzo AE, Romalde JL. Experimental Pseudomonas anguilliseptica infection in turbot Psetta maxima (L.): a histopathological and immunohistochemical study. Eur J Histochem 2009;53:73-80

58. Squillacioti C, De Luca A, Paino S, Langella E, Mirabella N. Effects of castration on the expression of the NGF and TrkA in the vas deferens and accessory male genital glands of the rat. Eur $\mathrm{J}$ Histochem 2009;53:239-48.

59. Battistelli S, Citterio B, Baldelli B, Parlani C, Malatesta M. Histochemical and morphometrical study of mouse intestine epithelium after a long term diet containing genetically modified soybean. Eur J Histochem 2010;54:e36.

60. Costa CAX, de Brito KNO, Gomes MA, Caliari MV. Histopathological and immunohistochemical study of the hepatic lesions experimentally induced by Entamoeba dispar. Eur J Histochem 2010;54:e39.

61. Ferrandino I, Favorito R, Grimaldi MC. Cadmium induces changes on ACTH and PRL cells in Podarcis sicula Lizard pituitary gland. Eur J Histochem 2010;54:e45.

62. Karaca T, Bayiroglu F, Yoruk MU, Kaya S, Uslu S, Comba B, et al. Effect of Royal Jelly on experimental colitis induced by acetic acid and alteration of mast cell distribution in the colon of rats. Eur $\mathrm{J}$ Histochem 2010;54:e35.

63. Kopera I, Durlej M, Hejmej A, KnapczykStwora K, Duda M, Slomczynska M, et al. Effects of pre- and postnatal exposure to flutamide on connexin 43 expression in testes and ovaries of prepubertal pigs. Eur J Histochem 2010;54:e15.

64. Kovsca Janjatovic A, Lacković G, Bozic F, Kezic D, Popovic M, Valpotić H, et al. Histomorphometric evaluation of intestinal cellular immune responses in pigs immunized with live oral F4ac+ nonenterotoxigenic E. coli vaccine against postweaning colibacillosis. Eur J Histochem 2010;54:e4.

65. Valpotić H, Kovšca Janjatović A, Lacković G, Božić F, Dobranić V, Svoboda $\mathrm{D}$, et al. Increased number of intestinal villous $\mathrm{M}$ cells in levamisole - pretreated weaned pigs experimentally infected with F4ac+ enterotoxigenic Escherichia coli strain. Eur J Histochem 2010;54:e18.

66. Vatsos IN, Kotzamanis Y, Henry M,
Angelidis P, Alexis M. Monitoring stress in fish by applying image analysis to their skin mucous cells. Eur J Histochem 2010;54:e22.

67. Marziliano N, Arbustini E, Rossi de Gasperis M, Crovella S. Detection of Epstein Barr virus in formalin-fixed paraffin tissues by fluorescent direct in situ PCR. Eur J Histochem 2005;49:30912.

68. Soldani C, Scovassi AI, Canosi U, Bramucci E, Ardissino D, Arbustini E. Multicolor fluorescence technique to detect apoptotic cells in advanced coronary atherosclerotic plaques. Eur J Histochem 2005;49:47-52.

69. Taupin P. Processing scarce biological samples for light and transmission electron microscopy. Eur J Histochem 2008;52:135-9.

70. Cardani R, Mancinelli E, Giagnacovo M, Sansone V, Meola G. Ribonuclear inclusions as biomarker of myotonic dystrophy type 2 , even in improperly frozen or defrozen skeletal muscle biopsies. Eur J Histochem 2009;53:107-12.

71. Giagnacovo M, Cardani R, Meola G, Pellicciari C, Malatesta M. Routinely frozen biopsies of human skeletal muscle are suitable for morphological and immunocytochemical analyses at transmission electron microscopy. Eur J Histochem 2010;54:e31.

72. Relucenti M, Heyn R, Petruzziello L, Pugliese G, Taurino M, Familiari G. Detecting microcalcifications in atherosclerotic plaques by a simple trichromic staining method for epoxy embedded carotid endarterectomies. Eur J Histochem 2010;54:e33.

73. Smerdu V, Soukup T. Demonstration of myosin heavy chain isoforms in rat and humans: the specificity of seven available monoclonal antibodies used in immunohistochemical and immunoblotting methods. Eur J Histochem 2008; 52:179-90

74. Galbo T, Pedersen IL, Fløyel T, BangBerthelsen CH, Serup P, Madsen OD, et al. Novel monoclonal antibodies against Pdx1 reveal feedback regulation of Pdx1 protein levels. Eur J Histochem 2010; 54:e19.

75. Nemolato S, Serra S, Saccani S, Faa G. Deparaffination time: a crucial point in histochemical detection of tissue copper. Eur J Histochem 2008;52:175-8.

76. Petr T, Šmíd V, Šmídová J, Hůlková H, Jirkovská M, Elleder M, et al. Histo chemical detection of GM1 ganglioside using cholera toxin-B subunit. Evaluation of critical factors optimal for in situ detection with special emphasis to acetone pre-extraction. Eur J Histochem 2010;54:e23.

77. Al-Zghoul MB, Al-Rukibat RK, M Alghadi, Caceci T, Bani Ismail Z. Distribution and density of mast cells in camel small intestine and influence of fixation techniques. Eur J Histochem 2008;52:237-42.

78. Shi C, Zhou G, Zhu Y, Su Y, Cheng T, Zhau HE, et al. Quantum dots-based multiplexed immunohistochemistry of protein expression in human prostate cancer cells. Eur J Histochem 2008;52:127-34.

79. Xue J, Chen H, Diao L, Chen X, Xia D. Expression of Caveolin-1 in tongue squamous cell carcinoma by quantum dots. Eur J Histochem 2010;54:e20.

80. Diaz-Zamboni JE, Adur JF, Vicente $\mathrm{N}$, Fiorucci MP, Izaguirre MF, Casco VH. 3D automatic quantification applied to optically sectioned images to improve microscopy analysis. Eur J Histochem 2008;52:115-26.

81. Karen P, Stevanec M, Smerdu V, Cvetko E, Kubínová L, Erzen I. Software for muscle fibre type classification and analysis. Eur J Histochem 2009;53:87-95.

82. Cremer M, Zinner R, Stein S, Albiez H, Wagler B, Cremer C, et al. Three dimensional analysis of histone methylation patterns in normal and tumor cell nuclei. Eur J Histochem 2004;48:15-28.

83. Fakan S. Ultrastructural cytochemical analyses of nuclear functional architecture. Eur J Histochem 2004;48:5-14.

84. Cremer T, Cremer C. Rise, fall and resurrection of chromosome territories: a historical perspective. Part I. The rise of chromosome territories. Eur J Histochem 2006;50:161-76.

85. Cremer T, Cremer C. Rise, fall and resurrection of chromosome territories: a historical perspective. Part II. Fall and resurrection of chromosome territories during the 1950 s to $1980 \mathrm{~s}$. Part III. Chromosome territories and the functional nuclear architecture: experiments and models from the 1990s to the present. Eur J Histochem 2006;50:223-72.

86. Smetana K, Klamová H, Mikulenková D, Pluskalová M, Hrkal Z. On the nucleolar size and density in human early granulocytic progenitors, myeloblasts. Eur J Histochem 2006;50:119-24.

87. Soldani C, Bottone MG, Pellicciari C, Scovassi AI. Nucleolus disassembly in mitosis and apoptosis: dynamic redistribution of phosphorylated-c-Myc, fibrillarin and Ki-67. Eur J Histochem 2006;50:273-80.

88. Maraldi NM, Mazzotti G, Rana R, Antonucci A, Di Primio R, Guidotti L. The nuclear envelope, human genetic 
diseases and ageing. Eur J Histochem 2007; 51(Suppl 1):117-24.

89. Smetana K, Kuzelova K, Zápotocký M, Starková J, Hrkal Z, Trka J. Mean diameter of nucleolar bodies in cultured human leukemic myeloblasts is mainly related to the $\mathrm{S}$ and $\mathrm{G} 2$ phase of the cell cycle. Eur J Histochem. 2007;51:269-74.

90. Smetana K, Zápotocky M, Starková J, Trka J. To the nucleolar density and size in apoptotic human leukemic myeloblasts produced in vitro by Trichostatin A. Eur J Histochem 2008; 52:143-8

91. Maraldi NM, Lattanzi G, Capanni C, Columbaro M, Merlini L, Mattioli E, et al. Nuclear envelope proteins and chromatin arrangement: a pathogenic mechanism for laminopathies. Eur $\mathbf{J}$ Histochem 2006; 50:1-8.

92. Dominici S, Fiori V, Magnani M, Schena E, Capanni C, Camozzi D, et al. Different prelamin A forms accumulate in human fibroblasts: a study in experimental models and progeria. Eur $\mathrm{J}$ Histochem 2009;53:43-52.

93. Malatesta M, Perdoni F, Muller S, Zancanaro C, Pellicciari C. Nuclei of aged myofibres undergo structural and functional changes suggesting impairment in RNA processing. Eur $\mathrm{J}$ Histochem 2009;53:97-106.

94. Malatesta M, Meola G. Structural and functional alterations of the cell nucleus in skeletal muscle wasting: the evidence in situ. Eur J Histochem 2010;54:e44.

95. Manfredi Romanini MG. Nuclear histochemistry: its history in fifty volumes. Eur J Histochem 2006;50:79-81.

96. Meola G. Advanced microscopic and histochemical techniques: diagnostic tools in the molecular era of myology. Eur $\mathrm{J}$ Histochem 2005;49:93-6.

97. Musarò A, Giacinti C, Pelosi L, Dobrowolny G, Barberi L, Nardis C, et al. Stem cell-mediated muscle regeneration and repair in aging and neuromuscular diseases. Eur J Histochem 2007; 51(Suppl 1):35-44.

98. Cardani R, Mancinelli E, Rotondo G, Sansone V, Meola G. Muscleblind-like protein 1 nuclear sequestration is a molecular pathology marker of DM1 and DM2. Eur J Histochem 2006;50:177-82.

99. Perdoni F, Malatesta M, Cardani R, Giagnacovo M, Mancinelli E, Meola G, et al. RNA/MBNL1-containing foci in myoblast nuclei from patients affected by myotonic dystrophy type 2: an immunocytochemical study. Eur J Histochem 2009;53:151-8.

100. Malatesta M, Perdoni F, Muller S, Pellicciari C, Zancanaro C. Pre-mRNA processing is partially impaired in satellite cell nuclei from aged muscles. J Biomed Biotechnol vol. 2010, Article ID 410405.

101. Lehnert M, Laurer H, Maier B, Frank J, Marzi I, Steudel WI, et al. The histochemical profile of the rat extensor digitorum longus muscle differentiates after birth and dedifferentiates in senescence. Eur J Histochem 2007;51:111-8.

102. Cataldi A, Zara S, Rapino M, Zingariello M, di Giacomo V, Antonucci A. p53 and telomerase control rat myocardial tissue response to hypoxia and ageing. Eur $\mathrm{J}$ Histochem 2009;53:209-16.

103. Huang H, Wang W, Liu P, Jiang Y, Zhao Y, Wei $\mathrm{H}$ et al. TRPC1 expression and distribution in rat hearts. Eur J Histochem 2009;53:217-24.

104. Anastasi G, Cutroneo G, Santoro G, Arco A, Rizzo G, Trommino C, et al. Integrins, muscle agrin and sarcoglycans during muscular inactivity conditions: an immunohistochemical study. Eur J Histochem 2006;50:327-36.

105. Bellafiore M, Cappello F, Palumbo D, Macaluso F, Bianco A, Palma A, et al. Increased expression of titin in mouse gastrocnemius muscle in response to an endurance-training program. Eur J Histochem 2007;51:119-24.

106. Nanci A, Wazen R, Nishio C, Zalzal SF. Immunocytochemistry of matrix proteins in calcified tissues: functional biochemistry on section. Eur J Histochem 2008;52:201-14.

107. Li JY, Hu B, Wang XJ, Wang SL. Temporal and spatial expression of TGF-b 2 in tooth crown development in mouse first lower molar. Eur J Histochem 2008;52:243-50.

108. Orsini G, Ruggeri A, Mazzoni A, Nato F, Falconi M, Putignano A, et al. Immunohistochemical localization of dentin matrix protein 1 in human dentin. Eur $\mathrm{J}$ Histochem 2008;52:215-20.

109. Ruggeri A, Orsini G, Mazzoni A, Nato F, Papa V, Piccirilli M, et al. Immunohistochemical and biochemical assay of versican in human sound predentine/ dentine matrix. Eur J Histochem 2009; 53:125-34

110. Nicolin V, Narducci P, Celeghini C. Effect of recombinant TRAIL in a murine coculture system of osteoclastogenesis. Eur J Histochem 2008;52:75-8.

111. Narducci P, Bortul R, Bareggi R, Nicolin $\mathrm{V}$. Clathrin-dependent endocytosis of membrane-bound RANKL in differentiated osteoclasts. Eur J Histochem 2010; 54:e6.

112. Nicolin V, Dal Piaz F, S. Nori L, Narducci $\mathrm{P}$, De Tommasi N. Inhibition of bone resorption by Tanshinone VI isolated from Salvia miltiorrhiza Bunge. Eur J Histochem 2010;54:e21.

113. Gigante A, Manzotti S, Bevilacqua C, Orciani M, Di Primio R, MattioliBelmonte M. Adult mesenchymal stem cells for bone and cartilage engineering: effect of scaffold materials. Eur $\mathrm{J}$ Histochem 2008;52: 169-74.

114. Riccio M, Resca E, Maraldi T, Pisciotta A, Ferrari A, Bruzzesi G, et al. Human dental pulp stem cells produce mineralized matrix in 2D and 3D cultures. Eur $\mathrm{J}$ Histochem 2010;54:e46.

115. Casadei L, Vallorani L, Gioacchini AM, Guescini M, Burattini S, D'Emilio A, et al. Proteomics-based investigation in C2C12 myoblast differentiation. Eur J Histochem 2009;53:261-8.

116. Bugorsky R, Perriard JC, Vassalli G. Genetic selection system allowing monitoring of myofibrillogenesis in living cardiomyocytes derived from mouse embryonic stem cells. Eur J Histochem 2008; 52:1-10.

117. Corallini F, Gonelli A, D’Aurizio F, di Iasio MG, Vaccarezza, M. Mesenchymal stem cells-derived vascular smooth muscle cells release abundant levels of osteoprotegerin. Eur J Histochem 2009; 53:19-24.

118. Boiani M, Crosetto N, Redi CA. Pavia symposium on embryos and stem cells. Eur J Histochem 2008;52:79-81.

119. Cisterna B, Flach F, Vecchio L, Barabino SML, Battistelli S, Martin TE, et al. Can a genetically-modified organism-containing diet influence embryo development? A preliminary study on preimplantation mouse embryos Eur J Histochem 2008;52:263-7.

120. Liang Y, Huang L, Yang J. Differential expression of ryanodine receptor in the developing rat cochlea. Eur J Histochem 2009;53:249-60.

121. Lodde V, Modina SC, Franciosi F, Zuccari E, Tessaro I, Luciano A. M. Localization of DNA methyltransferase-1 during oocyte differentiation, in vitro maturation and early embryonic development in cow. Eur J Histochem 2009;53:199-208.

122. Mercati F, Pascucci L, Ceccarelli P, Dall'Aglio C, Pedini V, Gargiulo AM. Expression of mesenchymal stem cell marker CD90 on dermal sheath cells of the anagen hair follicle in canine species. Eur J Histochem 2009;53:15966.

123. Pennati R, Groppelli S, De Bernardi F, Mastrototaro F, Zega G. Immunohistochemical analysis of adhesive papillae of Clavelina lepadiformis (Müller, 1776) and Clavelina phlegraea (Salfi, 1929) 
(Tunicata, Ascidiacea). Eur J Histochem 2009;53:25-34.

124. Vaccaro R, Parisi Salvi E, Nofroni I, D’Este I, Baglaj SM, Renda T. Endocrine cells in atresic chick embryo intestine: histochemical and immunohistochemical study. Eur J Histochem 2009;53:14350.

125. Kluchova D, Bolakova A, Heichel C, Bron AJ, Kozak I. NADPH-diaphorase expression in the Meibonian glands of rat palpebra in postnatal development. Eur J Histochem 2010;54:e47.

126. Lacunza E, Ferretti V, Barbeito C, SegalEiras A, Croce MV. Immunohistochemical evidence of Mucl expression during rat embryonic development. Eur J
Histochem 2010;54:e49.

127. Lorenzi T, Turi A, Crescimanno C, Morroni M, Castellucci M, David G, et al. Syndecan expressions in the human amnion and chorionic plate. Eur J Histochem 2010;54: e42.

128. Radaelli G, Poltronieri C, Simontacchi C, Negrato E, Pascoli F, Libertini A, et al. Immuno-histochemical localization of IGF-I, IGF-II and MSTN proteins during development of triploid sea bass (Dicentrarchus labrax). Eur J Histochem 2010;54:e16.

129. De Luca A, Squillacioti C, Pero ME, Paino S, Langella E, Mirabella N. Urocortin-like immunoreactivity in the primary lymphoid organs of the duck
(Anas platyrhynchos). Eur J Histochem 2009;53:167-76.

130. Aita M, Benedetti F, Carafelli E, Caccia E, Romano N. Effects of hypophyseal or thymic allograft on thymus development in partially decerebrate chicken embryos: expression of PCNA and CD3 markers. Eur J Histochem 2010;54:e37.

131. Berger J. Nucleolar size in lymphocytes and haemocytes of different species. Eur J Histochem 2008;52:149-52.

132. Matozzo V, Marin MG. First cytochemical study of haemocytes from the crab Carcinus aestuarii (Crustacea, Decapoda). Eur J Histochem 2010;54:e9. 